\title{
Effects of Experimentally Induced Nicotine on the Liver of Neonatal Albino Rat
}

\author{
Hager S. Marzouk ${ }^{1}$, Ashraf S. Awaad ${ }^{2 *}$, Rasha E. Abo-Eleneen ${ }^{1}$, Ahlam M. El-Bakry ${ }^{1}$ \\ ${ }^{1}$ Department of Zoology-Faculty of Science, Beni-Suef University, Egypt; ${ }^{2}$ Department of Anatomy and Embryology- \\ Faculty of Veterinary medicine, Beni-Suef University, Egypt.
}

\begin{abstract}
Nicotine, the most important constituent of tobacco, is responsible for habit forming properties of tobacco chewing and cigarette smoking. Nicotine exposure is also associated with a variety of organ damage. Therefore, the objective of this study was to show the effects of different nicotine states on liver of rat newborns at postnatal days (PNDs) 7, 14 and 21. Nicotine was intraperitoneally injected from gestation day 6 to lactation day 21. The animals were divided into three groups as follows (1) Group A, mothers were treated with saline (control group); (2) Group $\mathrm{B}$, mothers were given nicotine $(0.5 \mathrm{mg} / \mathrm{kg})$ and (3) Group C, mothers were given nicotine $(1.5 \mathrm{mg} / \mathrm{kg})$. The results showed that nicotine exposure caused significant elevation of alanine transaminase (ALT), aspirate transaminase (AST), in hepatic tissues and reduced plasma total protein and antioxidant parameters (glutathione; GSH, superoxide dismutase; SOD and catalase; CAT). The liver in the nicotine-treated group showed degenerative changes as vacuolated cytoplasm of hepatocytes, congestion of central vein and dilated sinusoids, necrosis and inflammation. These changes increased as nicotine dose increased and the age progress. The result indicated that nicotine induced a degenerative effect on the liver of the neonates and these alterations, on both treated groups, were age and dose dependent.
\end{abstract}

Keywords | Nicotine, Neonates, Liver, Histopathology, Oxidative stress, Antioxidant enzyme

Received | September 23, 2021; Accepted | October 11, 2021; Published | December 01, 2021

*Correspondence | Ashraf Sayed Awaad, Department of Anatomy and Embryology- Faculty of Veterinary medicine, Beni-Suef University, Egypt; Email: awaad2000@gmail.com

Citation | Marzouk HS, Awaad AS, Abo-Eleneen RE, El-Bakry AM (2022). Effects of experimentally induced nicotine on the liver of neonatal albino rat. Adv. Anim. Vet. Sci. 10(1): 151-159.

DOI | http://dx.doi.org/10.17582/journal.aavs/2022/10.1.151.159

ISSN (Online) | 2307-8316; ISSN (Print) | 2309-3331

Copyright (C) 2022 Marzouk et al. This is an open access article distributed under the Creative Commons Attribution License, which permits unrestricted use, distribution, and reproduction in any medium, provided the original work is properly cited.

\section{INTRODUCTION}

$T_{1}$ obacco has dangerous effect on human health, it still highly consumed throughout the world (Benowitz et al., 1988). Nowadays, smoking is one of the most dangerous common addictions. Moreover, many toxic and carcinogenic compounds harmful to the health can be generated by cigarette smoking, like; nicotine, nitrogen oxides, hydrogen cyanide, carbon monoxide and free radicals (Hoffmann et al., 2001).

Nicotine is a volatile and highly toxic colorless, natural liquid alkaloid, on exposure to the air it turns brown and acquires the odour of tobacco. As a major constituent of tobacco, it is probably the cause of the smokinginduced organ malfunction, it is metabolized rapidly and extensively in the liver, and to a lesser extent in the lungs and kidneys (Gorrod and Jenner, 1975). About, 70-75 \% of the total nicotine elimination is through the renal excretion (Rosenberg et al., 1980). It also excreted in the lactating smoking women milk (Goodman and Gilman, 1991).

Prenatal and postnatal exposure to nicotine and cigarette smoke have been shown to affect pregnancy outcome (Shacka, et al., 1997; Zaren et al., 1997) and to have detrimental effects on the development of fetuses and neonates (Rowell and Clark, 1982; Cnattingius and Nordstrom, 1996). Nicotine exposure is also associated with a variety of organ damage (von-Ziegler et al., 1991; Maritz and Burger, 1992; Cutz et al., 1996). The effects of nicotine include modulation of enzyme activities in the lung, kidney, and liver (Bilimoria and Ecobichon, 1989; 
Maritz and Burger, 1992).

There is increasing evidence that cellular damage that occurs with nicotine exposure is associated with an imbalance in the cellular oxidant-antioxidant system (Wetscher et al., 1995; Ashakumary and Vijayammal, 1996). Nicotine administration leads to the production of superoxide free radicals which, induces ischemia and gastric mucosal damage (Smith et al., 1987) and the pathogenesis of atherosclerosis in rats by increased lipid peroxidation (Ashakumary and Vijayammal, 1996). Lipid peroxidation is also a cause of oxidative stress when pancreatic tissue or esophageal mucosa is incubated with nicotine (Wetscher et al., 1995). Defenses against these oxygen free radicals are several antioxidant enzymes, including superoxide dismutase (SOD). SOD, an oxygen free radical scavenging enzyme, has been shown to be a cellular protective enzyme in bowel ischemia and gastric lesion formation (Dalsing et al., 1983; Parks et al., 1983), and in studies using pancreatic tissues or esophageal mucosa incubated with nicotine (Wetscher et al., 1995).

Prenatal exposure of nicotine is a risk factor for developing an addiction at a later stage in life (Christensen et al., 2015). The majority of smoking women during pregnancy developed their intemperance to tobacco in early life, thus there is a clear poverty to intervene in the familial transmission of nicotine reliance (Tessa, 2019). Previous studies have indicated that nicotine is potentially hepatotoxic, as shown by the histomorphological changes in the liver in nulliparous female rats and in pregnant rats (Yuen et al., 1995). However, few data are available on the hepatotoxic effects of nicotine on the fetus or newborn when nicotine is administered to the mothers during pregnancy or lactation. The present study aimed to evaluate the effects of different doses of nicotine on liver of postnatal albino rats.

\section{MATERIALS AND METHODS}

\section{Nicotine STRUCTURE}

Nicotine was purchased from Sigma (C6499, USA). Chemical name: 1-Metyl-2-3-pyridel- Pirolidin. Chemical formula: $\mathrm{C}_{10} \mathrm{H}_{14} \mathrm{~N}_{2}$. Half-life of 2 hours. Metabolism: hepatic. Molar mass: $162.23 \mathrm{~g} / \mathrm{mol}$ IUPC name: S-3-1(1-Methyl-2-Pyrrolidinyl) Pyridine (Figure 1).

\section{ETHICS STATEMENT}

The experimental work adhered to the recommendations of the experimental animal care and the official Committee of Beni-Suef University (BSU), Faculty of Science (BSU/ FS/ S/2016/11). Every effort was made to minimize the pain and distress of the experimental animals.

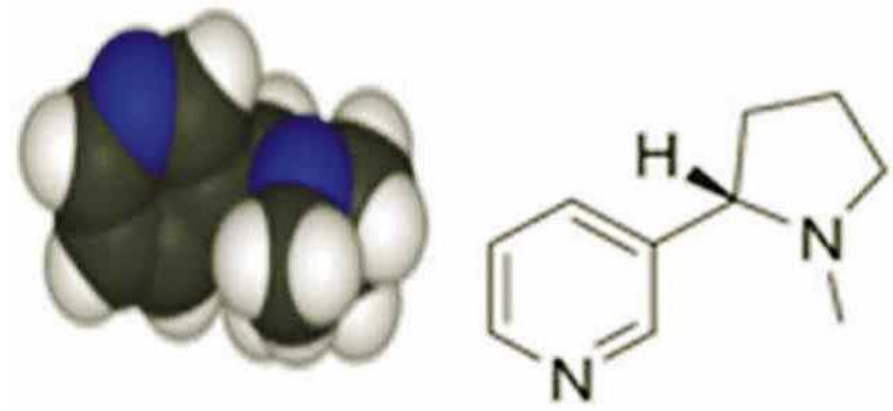

Figure 1: Nicotine Structural chemical formula (Jalili et al., 2014). $\mathrm{N}$ (nitrogen), $\mathrm{H}$ (hydrogen).

\section{EXPERIMENTAL ANIMALS}

Forty apparently healthy mature female Wistar rats (Rattus norvegicus) from order Rodentia and family Muridae, weighing $180 \pm 200 \mathrm{gm}$, and twenty adult males Wistar rats (Rattus norvegicus) for mating only were procured from Egypt's National Institute of Ophthalmology in Giza. The adult rats were kept under observation for 2 weeks in the department animal house to exclude any intercurrent infection and to acclimatize the new conditions. Rats were kept in standard cages with normal atmospheric conditions $\left(25 \pm 2{ }^{\circ} \mathrm{C}, 50 \pm 2 \%\right.$ humidity, and 12 -hour light cycle), and given rodent pellets and tap water as free access.

After this period, the vaginal smear of each female Wistar rat was examined to determine the estrus cycle. Then one adult male rat was mated with 2 proestrus female rats in a distinct cage for 1 or 2 consecutive days. The zero-day pregnancy was distinguished by the appearance of a vaginal plug and/or sperms in a vaginal smear. The pregnant animals were transferred into separate cages to start our experiment.

\section{EXPERIMENTAL SCHEDULE}

Nicotine is toxic, so the next steps will be followed to avoid its toxicity: Nicotine $(0.4 \mathrm{mg} / \mathrm{kg})$ was intraperitoneally injected for three consecutive days to animals in fixed times. The dosage was then raised and treated groups were injected with 0.5 and $1.5 \mathrm{mg} / \mathrm{kg}$ solution (Biala and Weglinska, 2004; Jalili et al., 2014).

The pregnant rats from the $6^{\text {th }}$ days of pregnancy to the 21 days of lactation (Nash and Persaud, 1988) were allocated into three groups as follows:-

Group A: Control group received $0.2 \mu$ i.p. of PBSS ( $\mathrm{pH}$ 7.4 ), from the $6^{\text {th }}$ days of pregnancy to the $21^{\text {st }}$ days of lactation. Group B: Treated group received $0.5 \mathrm{mg} / \mathrm{kg}$ of nicotine from $6^{\text {th }}$ day of gestation to the $21^{\text {st }}$ day of lactation. Group C: Treated group received $1.5 \mathrm{mg} / \mathrm{kg}$ of nicotine from $6^{\text {th }}$ day of gestation to the $21^{\text {st }}$ day of lactation.

After the pregnancy, the decapitation was carried out at postnatal days 7,14 and 21 under mild diethyl ether 
anesthesia. The blood samples were taken from jugular vein and allowed to coagulate at room temperature then centrifuged at 3000 r.p.m. for $30 \mathrm{~min}$. The clear nonhaemolyzed supernatant sera was quickly removed and kept at $-20^{\circ} \mathrm{C}$ for subsequent biochemical analysis.

\section{Histological pREPARATIONS}

Afterwards the animals were anesthetized under mild diethyl and dissected to get the liver. Slices of the liver were fixed in $10 \%$ neutral buffered formalin for $24 \mathrm{~h}$, they were dehydrated through ascending series of ethanol, cleared in xylene and embedded in paraffin wax. $5 \mu \mathrm{m}$ thick sections were stained with haematoxylin and eosin for histopathological studies (Bancroft and Gamble, 2002).

\section{The ASSAY OF SERUM BIOCHEMICAL}

Alanine amino transferase (ALT) (EC 2.6.1.2) and aspartate amino transferase (AST) (EC 2.6.1.1) activity were used according to the method of Schumann and Klauke (2003) with reagent kits purchased from Diamond Diagnostic (Egypt).

\section{ASSESSMENT OF OXIDATIVE STRESS AND ANTIOXIDANT} ENZYME ACTIVITY

The neonatal liver was removed immediately after a rapid anesthesia, dropped into the fixative of choice for general histological structure. Liver homogenate, obtained by grinding a small piece of freshly excised tissue in 10 volumes of $0.9 \% \mathrm{NaCl}(10 \% \mathrm{w} / \mathrm{v})$ using Teflon homogenizer (GlasCol, Terre Haute, USA). The supernatants were kept at $-20^{\circ} \mathrm{C}$ till use in the determination of LPO, SOD and CAT.

The activity of (LPO) in liver homogenate was determined according to the method of Yagi (1987). The activity of (SOD) (EC 1.15.1.1) in liver homogenate was assayed according to the method of Marklund and Marklund (1974). (CAT) activity in liver homogenate was assayed according to the method suggested by Cohen et al. (1970).

\section{Statistical ANALYSIS}

For data processing, GraphPad Prism 5 (GraphPad Software Inc., La Jolla, CA, USA) was used. Data were presented as mean $+/-\mathrm{SD}$. Comparison among groups is done using One-Way Analysis of Variance (ANOVA) followed by Bonferroni Multiple comparison posthoc test.

A statistically significant difference was described as a $(\mathrm{P})$ value where $\mathrm{P}<0.001$ is highly significant

\section{RESULTS AND DISCUSSION}

Histological analysis of THE LiVER TISSUE

In the control group (Group A) (Figures 2, 3, 4A, B), it was observed the structure of the liver, each lobule has a central vein, hepatic cords in radiating shape and normal capillaries form without inflammatory cells.
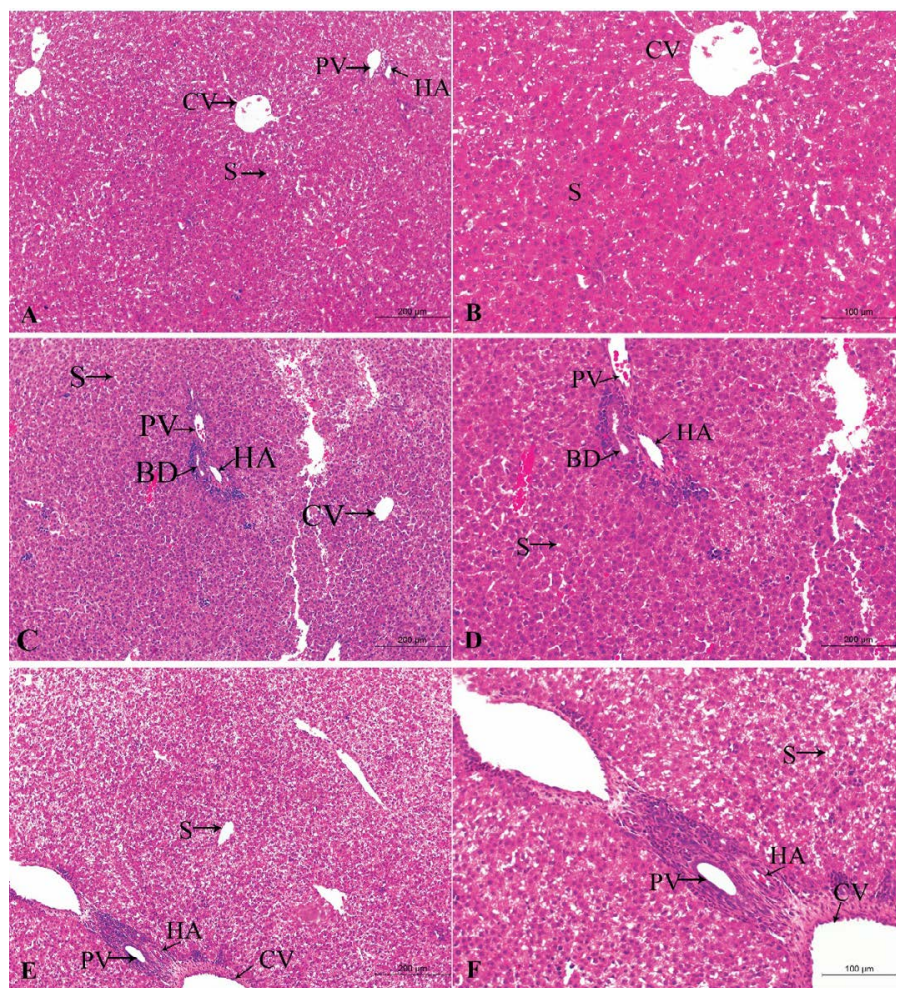

Figure 2: A photomicrograph of the neonatal liver at PND 7 showing the normal liver tissue in Group A (A, X100; B, $\mathrm{X} 400)$ and the pathological effects of nicotine on the liver in Group B (C,X100; D, X400) and Group C (E, X100; F, $X 400)$. Central vein (CV), Portal vein(PV), Hepatic artery branch (HA), Bile duct (BD), Sinusoid (S).

\section{IN THE POSTNATAL DAY 7}

Figures 2A, B, C, D, E, F in the treated group B, the section showed congested dilated central veins and blood sinusoid (Figure 2C). The affection of the portal area was in the form of congestion and dilatation of the portal veins with hyperplasia of the bile duct as well as cellular infiltration (Figure 2D).

In the treated group $\mathrm{C}$, sever lesions in liver tissue represented by marked congestion of central veins and blood sinusoid, degenerative changes and leucocytic infiltration (Figure $2 \mathrm{E})$. The tissue section revealed congestion in the portal area, marked bile duct hyperplasia, and cellular infiltration (Figure 2F).

\section{IN THE POSTNATAL DAY 14}

Figures $3 \mathrm{~A}, \mathrm{~B}, \mathrm{C}, \mathrm{D}, \mathrm{E}, \mathrm{F}$ in the treated group B, congestion increased in central veins and dilatation of blood sinusoid, leukocytic infiltration, and necrotic changes. Loss of normal arrangement of hepatocytes and most hepatocytes showed marked vacuolated cytoplasm with darkly stained nuclei (Figures 3C, D). 


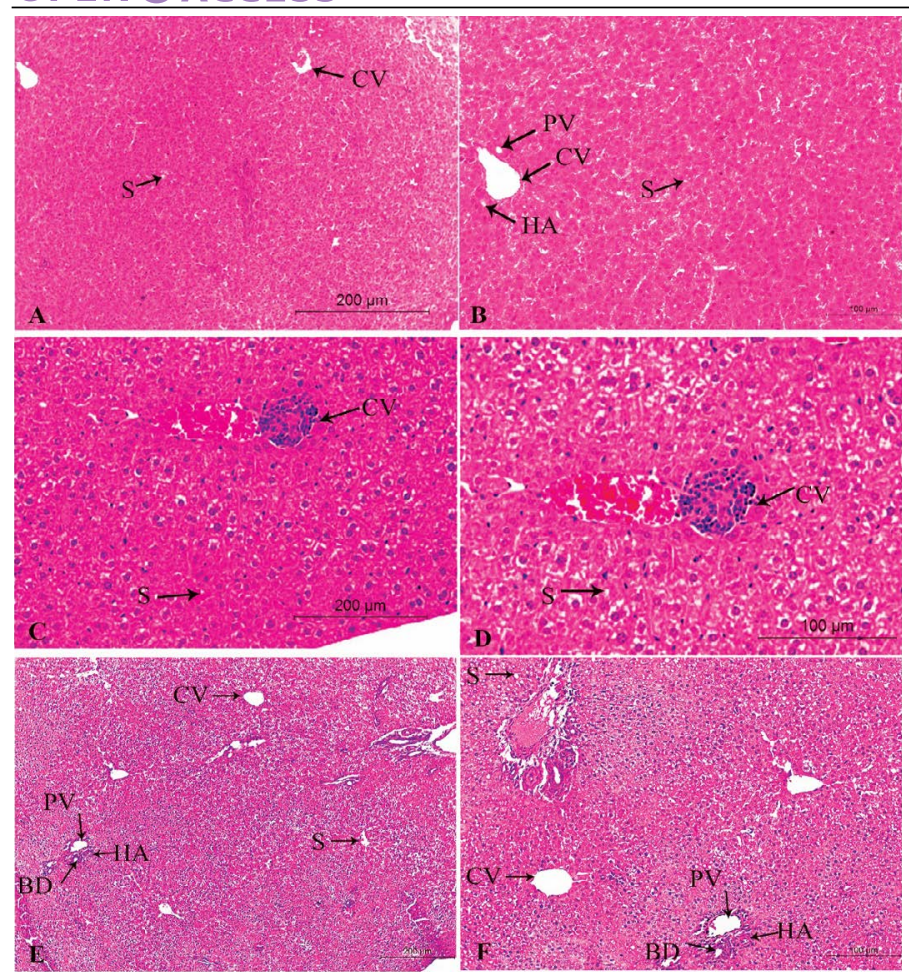

Figure 3: A photomicrograph of the neonatal liver at PND 14 showing the normal liver tissue in Group A (A, $\mathrm{X} 100 ; \mathrm{B}, \mathrm{X} 400)$ and the pathological effects of nicotine on the liver in Group B (C, X100; D, X400) and Group C (E, X100; F, X400). Central vein (CV), Portal vein(PV), Hepatic artery branch (HA), Bile duct (BD), Sinusoid (S).

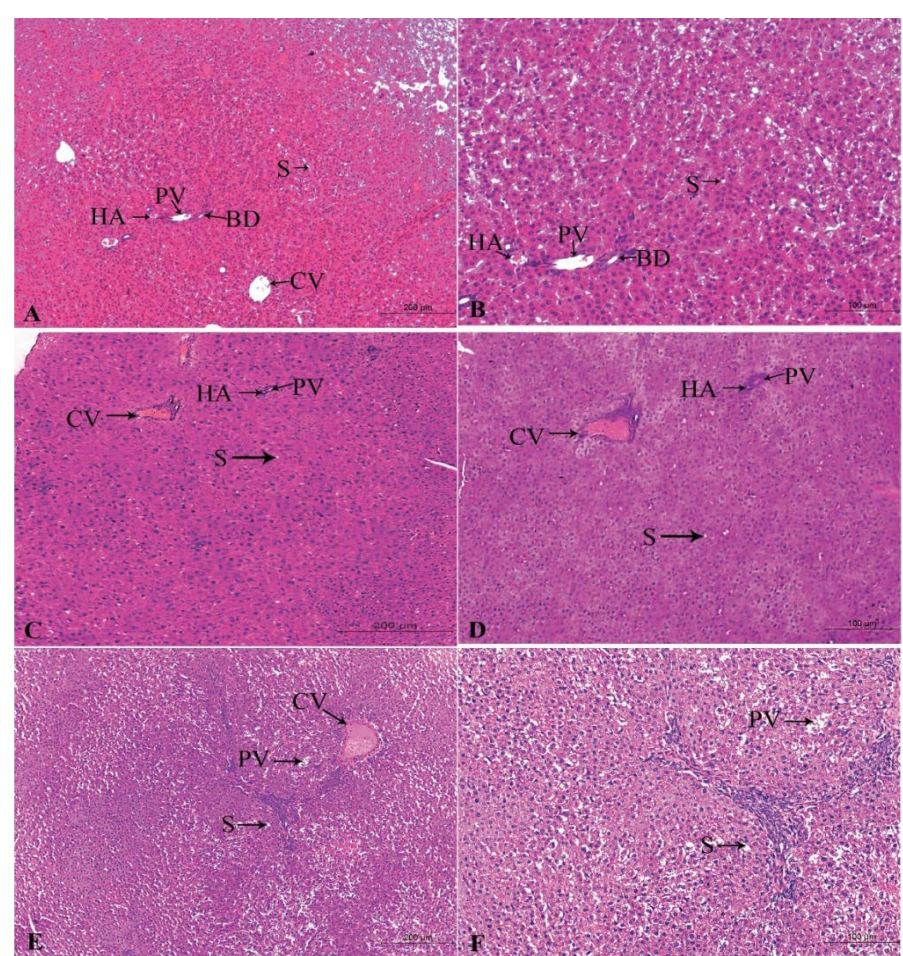

Figure 4: A photomicrograph of the neonatal liver at PND 21 showing the normal liver tissue in Group A (A, $\mathrm{X} 100 ; \mathrm{B}, \mathrm{X} 400)$ and the pathological effects of nicotine on the liver in Group B (C, X100; D, X400) and Group C (E, X100; F, X400). Central vein (CV), Portal vein(PV), Hepatic artery branch (HA), Bile duct (BD), Sinusoid (S).
In the treated group $\mathrm{C}$, increased in the bloodshot and dilatation in the central vein and blood sinusoid, increasing hypercellularity and necrotic changes, cellular infiltration, and degenerative changes in hepatocytes arrangement (Figures 3E, F).

\section{IN THE POSTNATAL DAY 21}

Figures 4A, B, C, D, E, F in the treated group B, severe congested dilated central veins and blood sinusoid, severe inflammation, and necrotic changes was seen. Moreover, there were hepatic cord degeneration and randomly spreading of hepatic cells (Figures 4C, D).

In the treated group $\mathrm{C}$, there were a degeneration of the hepatic normal structure, ballooned hepatocytes, severe necrotic changes, severe congestion in the portal area, and pyknosis (Figures 4E, F).

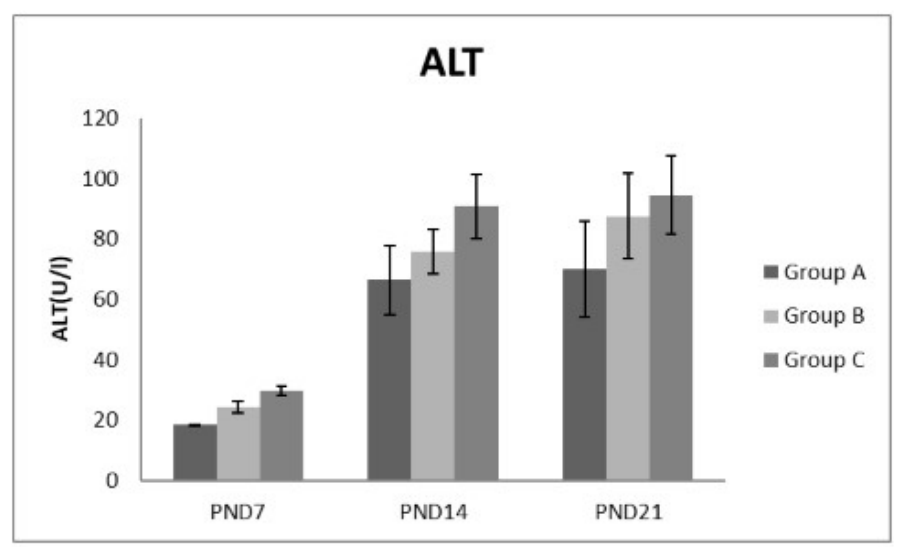

Figure 5: A photograph showing the effect of different nicotine doses on alanine transaminase (ALT) in blood serum of newborn at PND 7,14 and 21. Group A (Control group), Group B (0.5 mg/kg nicotine) and Group C (1.5 $\mathrm{mg} / \mathrm{kg}$ nicotine). Values were represented as Mean $\pm \mathrm{SD}$, $\mathrm{n}=8$ rats.

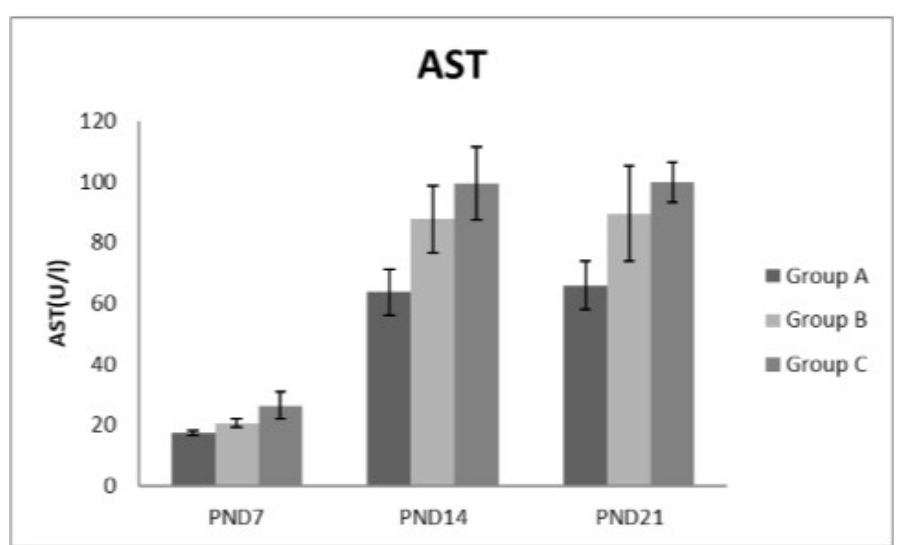

Figure 6: A photograph showing the effect of different nicotine doses on aspartate transaminase (AST) in blood serum of newborn at PND 7,14 and 21. Group A (Control group), Group B (0.5 mg/kg nicotine) and Group C (1.5 $\mathrm{mg} / \mathrm{kg}$ nicotine). Values were represented as Mean $\pm \mathrm{SD}$; $n=8$ rats. 
Effects of nicotine on alanine transaminase (ALT), aspartate transaminase (AST) and total protein Figures 5, 6, 7 treatments with nicotine in group $\mathrm{B}$ and $\mathrm{C}$ at $\mathrm{PND} 7$, 14 and 21 caused a significant rise in ALT, AST compared to the control group (Figures 5, 6). However, plasma total protein was significantly reduced as the age progress and the dose increased (Figure 7). These differences were very highly significant at $(\mathrm{P}<0.001)$.

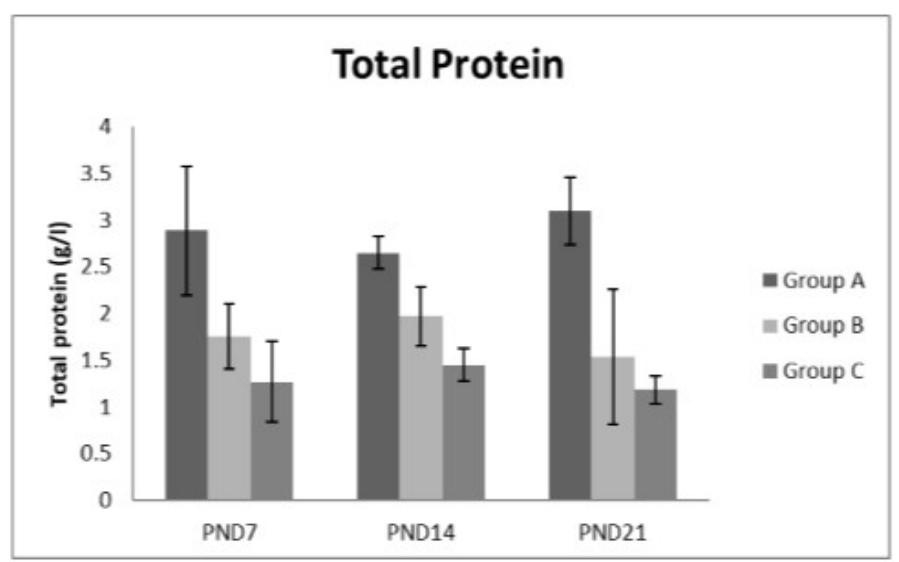

Figure 7: A photograph showing the effect of different nicotine doses on total protein in blood serum of newborn at PND 7,14 and 21. Group A (Control group), Group B $(0.5 \mathrm{mg} / \mathrm{kg}$ nicotine) and Group C (1.5 mg/ $\mathrm{kg}$ nicotine). Values were represented as Mean $\pm \mathrm{SD} ; \mathrm{n}=8$ rats.

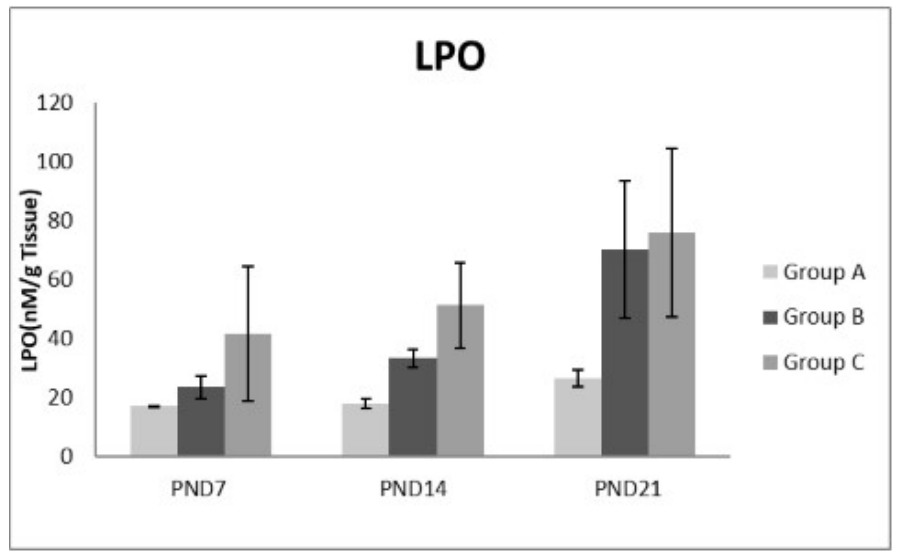

Figure 8: A photograph showing the effect of different nicotine doses on lipid peroxidase (LPO) in liver tissue of newborn at PND 7,14 and 21. Group A (Control group), Group B $(0.5 \mathrm{mg} / \mathrm{kg}$ nicotine) and Group C $(1.5 \mathrm{mg} / \mathrm{kg}$ nicotine). Values were represented as Mean $\pm S D ; n=8$ rats.

\section{OXIDATIVE STRESS PARAMETERS AND ANTIOXIDANT ENZYME}

Figures 8, 9, 10, 11 there was a significant increase in lipid peroxidation in nicotine treated group $\mathrm{B}$ and $\mathrm{C}$ at $\mathrm{PND} 7$, 14 and this increase became higher at PND 21 comparing to the control group. The depletion in GSH, SOD and CAT activity was observed in group $\mathrm{B}$ and $\mathrm{C}$ at PND 7, 14 and the reduction was more apparent at PND 21 compared to control group.

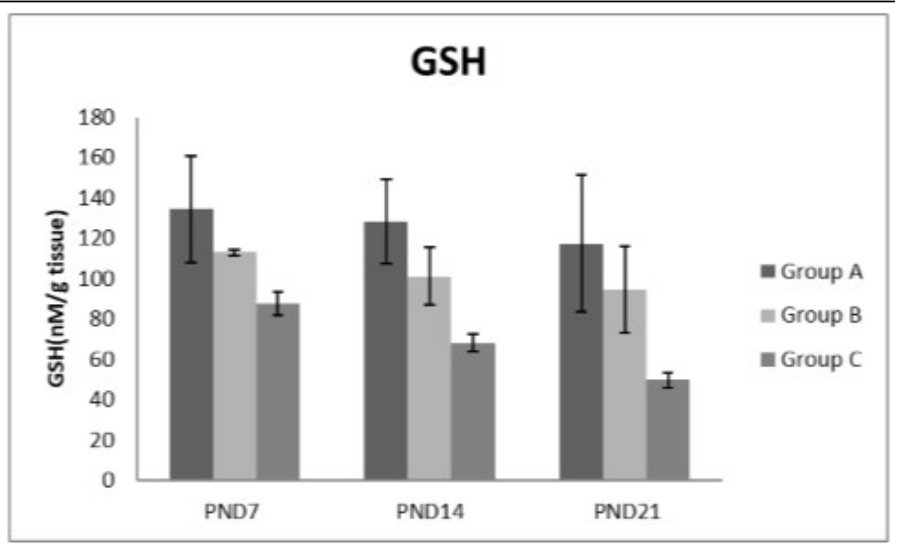

Figure 9: A photograph showing the effect of different nicotine doses on GSH in liver tissue of newborn at PND 7,14 and 21. Group A (Control group), Group B ( $0.5 \mathrm{mg} /$ $\mathrm{kg}$ nicotine) and Group C (1.5 mg/kg nicotine). Values were represented as Mean $\pm \mathrm{SD} ; \mathrm{n}=8$ rats.

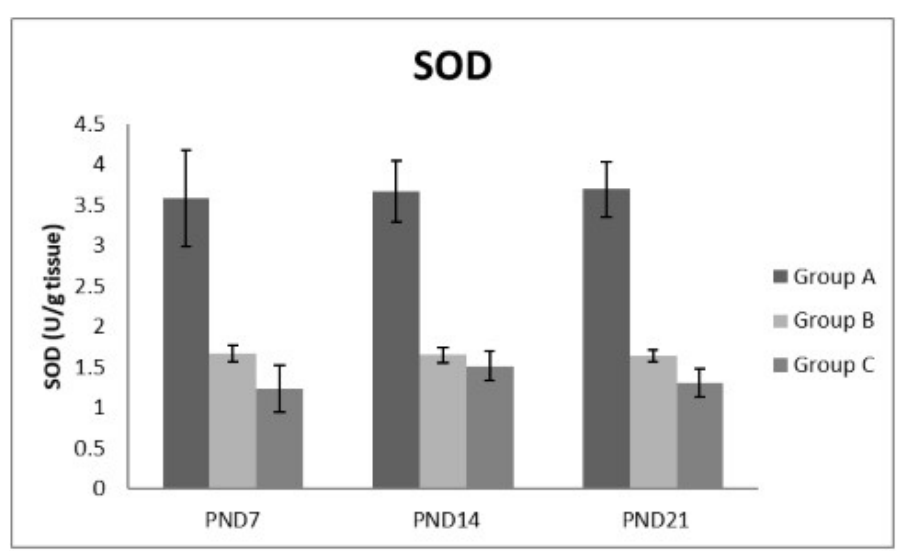

Figure 10: A photograph showing the effect of different nicotine doses on SOD in liver tissue of newborn at PND 7,14 and 21. Group A (Control group), Group B (0.5 mg/ $\mathrm{kg}$ nicotine) and Group $\mathrm{C}(1.5 \mathrm{mg} / \mathrm{kg}$ nicotine). Values were represented as Mean $\pm \mathrm{SD} ; \mathrm{n}=8$ rats.

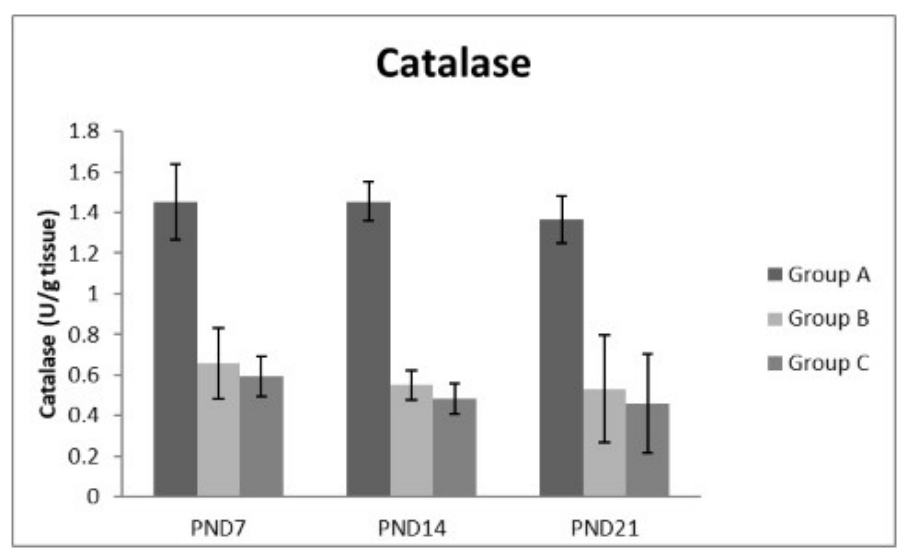

Figure 11: A photograph showing the effect of different nicotine doses on catalase in liver tissue of newborn at PND 7, 14 and 21. Group A (Control group), Group B (0.5 mg/kg nicotine) and Group C (1.5 mg/kg nicotine). Values were represented as Mean \pm SD; $n=8$ rats.

In tobacco, nicotine is the most important alkaloid 
compound which is biotransformed and removed by the liver together with other toxins, so it increased the risk of developing some dangerous hepatic disorders (Simeonova et al., 2014). Nicotine is metabolized in the liver and excreted through the kidney (Jaffe, 1990). The present study declared that, different doses of nicotine administration, as a drug, may affect the neonate's liver at PND 7, 14 and 21. This finding was possible due to the biochemical and histological tools. The results of the current research are important due to the great number of direct smokers and passive smoking people as well as the addicting treated people with nicotine to quit smoking. Even, nicotine inhalation as cigarette smoke leads to sever hepatic changes in the male adult rat much more than subcutaneous nicotine injected (Mamdouh et al., 2003).

Histological examination of the liver showed marked centrilobular congestion, dilatation of the central vein and the blood sinusoids, cellular degeneration with loss of trabecular arrangement in the nicotine-treated group. In addition, vacuoles appeared in many hepatocytes, indicating possible fatty changes. These changes increased with the dose dependent and the age progress. These results are concomitant with those of Marinucci et al. (2014) and Mahmoud and Amer (2014). In the lung and the liver of lactating offspring a histopathological changes happened due to oxidative stress induced by maternal nicotine exposure (Ozukutat, et al., 2005; Simeonova et al., 2014). Increasing in the caliber of the blood vessels was recorded as an obvious manifestation of nicotine treatment. The progressive dilatation of the vessels in the liver could be considered as a reaction change that might be related to increased levels of prostaglandin (PG) synthesis where these $\mathrm{PG}$ s induced smooth relaxation and consequent vasodilatation either directly or through releasing other vasodilator substances in blood (Backhle et al., 1979). The congestion and dilatation of the portal veins can be attributed to the portal hypertension resulted from the obstruction of the sinusoidal level due to degenerating ballooning hepatocytes (Walter and Israel, 1996). The infiltrating lymphocytes, in the portal areas and surrounding the lobules could be due to a defense reaction of the lobule against the toxicity of either inhaled cigarette smoke or injected nicotine which is metabolized in the liver (Gorrod and Jenner, 1975).

The efficiency of the hepatocytes to perform their metabolic functions is dependent on the incoming blood, which is influenced by the availability of oxygen and nutrients. This in turn is affected by the presence of toxic substances in the blood that bathes the hepatocytes. This explains the vacuolation of cytoplasm (Zhang and Ratchffe, 1993).

In current study different doses of nicotine treatment caused a significant elevation of liver enzymes; ALT and
AST at PNDs 7,14 and 21 compared to the control group and this indicating impaired liver function. This elevation increased as the age progress and the dose increased. This coincides with Fahim et al. (2014) who speculated that, there were a rise in both hepatic ALT and AST levels following I.P. nicotine injection $(1 \mathrm{mg} / \mathrm{Kg})$ for 3 weeks in mice. Some investigators claimed that, AST increased by cigarette smoking (Chan-Yeung et al., 1981; Alsalhen and Abdalsalam, 2014) as the present results support, while other studies argued that smoking did not influence AST or ALT (Tajima et al., 1988; Whitehead et al., 1996; Suriyaprom et al., 2007).

The present study also showed depletion in the levels of plasma total protein concentrations at PNDs 7, 14 and 21 compared to those in the control group with increasing the dose of nicotine and the age progress. These results are concomitant with those of Alsalhen and Abdalsalam (2014). The declination in the plasma protein and globulin was mainly due to the decrease in albumin level. Additionally, the blood protein depression may be due to loss of protein by reduce protein synthesis or increased proteolytic activity due to cigarette smoke exposure or via release of high levels of cellular oxidative free radicals could result increased proteolytic activity (Tetley, 2006). Also, the observed decrease in plasma protein of smokers could be attributed in part to the damaging effect of harmful compounds from cigarette smoking on liver cells (Jain et al., 2015).

Lipid alteration caused by smoking may be due to nicotine increases the sympathetic adrenal system thus increasing the secretion of catecholamines resulting in increased lipolysis and concentration of plasma free fatty acid consequently the secretion of hepatic free fatty acids and hepatic triglycerides along with VLDL-cholesterol in the blood stream (Austin, 1991).

Antioxidant enzymes are the primary defense as it prevents biological macromolecules from undergoing oxidative damage. However, nicotine disrupts the mitochondrial respiratory chain leading to increased generation of superoxide anions and hydrogen peroxide (Yildiz et al., 1998). Previous studies have suggested that hydrogen peroxide and superoxide anion are the main source of nicotine induced free radicals depleting the cellular antioxidants (Wetscher et al., 1995). The present study showed a significant decrease in both SOD and CAT activities, in all nicotine treated groups as the age progress and the dose increased; similar result was obtained by Ashakumari and Vijayammal (1996). The depletion in SOD activity was attributed to dispose of the free radicals of nicotine toxicity. Beside this, on nicotine administration, $\mathrm{H}_{2} \mathrm{O}_{2}$ produced by dismutation of superoxide anion, may have been efficiently converted to $\mathrm{O}_{2}$ by CAT and 
the enzyme activities showed a marked reduction. The depletion of antioxidant enzyme activity was may be due to inactivation of the enzyme proteins by nicotine-induced ROS generation, depletion of the enzyme substrates, and/or down-regulation of transcription and translation processes.

Glutathione was an important cellular reductant, which offers protections against free radicals, peroxide and toxic compounds. It is reformed from GSSG by donation of hydrogen from NADPH, the reaction being catalyzed by glutathione reductase (GR) (Meister, 1994; Speakman, 2003). In this study, a significant decrease in GSH level activity was observed in all nicotine treated groups with the age progress. These observations come in agreement with the result of Simeonova et al. (2014).

Free radicals are highly reactive atom, which damage the biological membrane through lipid peroxidation (Fraga, 1992). In the current investigation together with the results of Mahmoud and Amer (2014), Sheng et al. (2001), the enhancement of lipid peroxidation observed in all nicotine treated groups at PND7, 14 and 21 when compared with control group. Nicotine propagates the lipid peroxidation and serum aminotransferases. The former, damages the biological cell membrane of the liver and the latter are enzymes which act as sensitive indicators of hepatic cell damage (Rochling, 2001).

\section{CONCLUSIONS AND RECOMMENDATIONS}

The present study showed that, the Neonats of nicotine groups have higher level of lipid peroxides with the age and the dose increased, this accompanied by a significant decrease in the levels of GSH, (SOD), and (CAT) activity. Liver functions raised and total protein levels decreased. Nevertheless, both oxidative stress and liver dysfunction detected in this study may help to understand the higher risk of metabolic and vascular diseases in children whose mothers smoked during perinatal life. Further studies on the mechanisms of these associations are warranted.

\section{ACKNOWLEDGMENTS}

The authors sincere acknowledgement to all the staff of the lab of Zoology Faculty of Science and the lab of Histology and Pathology, Faculty of Veterinary Medicine, Beni-Suef University

\section{NOVELTY STATEMENT}

The current study, shows the hepatotoxic effects of nicotine on the fetus or newborn when nicotine is administered to the mothers during pregnancy or lactation and evaluate the effects of different doses of nicotine on liver of postnatal albino rats.

\section{AUTHOR'S CONTRIBUTION}

Hager S Marzouk collected literature then drafting the manuscript in consultation with Ashraf S. Awaad, Rasha E. Abo-Eleneen and Ahlam M El-Bakry. All authors approved the final manuscript.

\section{CONFLICT OF INTEREST}

The authors have declared no conflict of interest.

\section{REFERENCES}

-Alsalhen SK, Abdalsalam DR (2014). Effect of cigarette smoking on liver functions: A comparative study conducted among smokers and non-smokers male in El-beida City, Libya. 3(7): 291-295. https://doi.org/10.3329/icpj.v3i7.19077

-Ashakumary L, Vijayammal PL (1996).Additive effect of alcohol and nicotine on lipid peroxidation and antioxidant defence mechanism in rats.J. Appl.Toxicol., 16:305-308. https://doi. org/10.1002/(SICI)1099-1263(199607)16:4<305::AIDJAT353>3.0.CO;2-F

-Austin MA (1991). Plasma triglycerides and coronary heart disease. Arterio. Throm., 11: 2-14. https://doi. org/10.1161/01.ATV.11.1.2

- Backhle YS, Hartiala J, Toivonan H, Votilla P (1979). Effects of cigarette smoke on the metabolism of vasoactive hormones in the isolated rat lung. Br. J. Pharmacol., 65: 495-499. https://doi.org/10.1111/j.1476-5381.1979.tb07857.x

- Bancroft JD, Gamble M (2002). Theory and practice of histological techniques. Churichill Livingstone, Edinburgh, London. $6^{\text {th }}$ Edition.

- Benowitz NL, Porchet H, Sheiner L, Jacob P (1988). Nicotine absorption and cardiovascular effects with smokeless tobacco use: Comparison with cigarettes and nicotine gum. Clin. Pharmacol. Therapeut. 44(1): 23-28. https://doi. org/10.1038/clpt.1988.107

- Biala G, Weglinska B (2004). Calcium channel antagonists attenuate cross-sensitization to the rewarding and/or locomotor effects of nicotine, morphine and MK-801. J. Pharm. Pharmacol., 56(8): 1021-1028. https://doi. org/10.1211/0022357043888

- Bilimoria MH, Ecobichon DJ (1989). Subacute inhalation of cigarette smoke to pregnant and lactating rodents: $\mathrm{AHH}$ changes in perinatal tissues. J. Biochem. Toxicol., 4: 139146. https://doi.org/10.1002/jbt.2570040211

- Chan-Yeung M, Ferreira P, Frohlich J, Schulzer M, Tan F (1981). The effects of age, smoking, and alcohol on routine laboratory tests. Am.J. Clin.Pathol., 75(3): 320-326. https:// doi.org/10.1093/ajcp/75.3.320

- Christensen MH, Nielsen ML, Kohlmeier KA (2015). Electrophysiological changes in laterodorsal tegmental neurons associated with prenatal nicotine exposure: implications for heightened susceptibility to addict to drugs of abuse. J. Dev. Orig. Health Dis., 6(3): 182-200. https:// doi.org/10.1017/S204017441400049X

- Cnattingius S, Nordstrom ML (1996). Maternal smoking and 
feto-infant mortality: Biological pathways and public health significance. Acta Paediatr., 85:1400-1402. https://doi. org/10.1111/j.1651-2227.1996.tb13943.x

- Cohen G, Dembiec D, Marcus J (1970). Measurment of catalase activity in tissue extracts. Anal. Biochem., 34: 30-38. https:// doi.org/10.1016/0003-2697(70)90083-7

- Cutz E, Perrin DG, Hackman R, Czegledy-Nagy EN (1996). Maternal smoking and pulmonary neuroendocrine cells in sudden infant death syndrome. Pediatrics, 98: 668-672.

-Dalsing MC, Grosfeld JL, Schiffler MA, Vane DW, Hull M, Baehner RL, Weber TR (1983). Superoxide dismutase: A cellular protective enzyme in bowel ischemia.J Surg. Res., 34: 589-596. https://doi.org/10.1016/0022-4804(83)90115-4

- Fahim MA, Nemmar A,Al-Salam S, Dhanasekaran S, Shafiullah M, Yasin J, Hassan MY (2014). Thromboembolic injury and systemic toxicity induced by nicotine in mice. Gen. Physiol. Biophys., 33(3): 345-355. https://doi.org/10.4149/ gpb_2014012

- Fraga R (1992). Lipid peroxidation and free radical damage in cell. Free Radical Biol. Med., 3: 329-339.

- Goodman AG, Gilman SL (1991). The pharmacological basis of the therapeutics. Mac Millan Publishing Co. Inc., New York, $8^{\text {th }}$ edition.

- Gorrod JW, Jenner P (1975). The metabolism of tobacco alkaloids. Essays Toxicol. N. Y., 6: 35-78. https://doi. org/10.1016/B978-0-12-107606-1.50008-2

-Hoffmann D, Hoffmann I, El-Bayoumy K (2001). The less harmful cigarette: A controversial issue a tribute to Ernst $\mathrm{L}$. Wynder. Chem. Res. Toxicol., 14(7): 767-790. https://doi. org/10.1021/tx000260u

- Jaffe JH (1990). Drug addiction and drug abuse in A.G. Gilman, T.W. Rall, A.S. Niess, P. Taylor, (Eds.). Goodman Gillman's Pharmacol. Basis Therapeut., 8: 522-573.

- Jain A, Shruti Agrawal S, Swaran JS, Flora (2015). Arsenic and nicotine co-exposure lead to some synergistic effects onoxidative stress and apoptotic markers in young rat blood, liver, kidneys and brain. Toxicol. Rep., 2: 1334-1346. https:// doi.org/10.1016/j.toxrep.2015.09.003

-Jalili C, Salahshoor MR, Khademi F, Jalili P, Roshankhah SH (2014). Morphometrical analysis of the effect of nicotine administration on brain's prefrontal region in male rat. Int. J. Morphol., 32(3): 761-766. https://doi.org/10.4067/S071795022014000300003

- Mahmoud SG, Amer SA (2014). Protective effects of vitamin $\mathrm{C}$ against nicotine-induced oxidative damage of rat liver and kidney. IOSR J. Environ. Sci. Toxicol. Food Technol., 8(12): 50-63. https://doi.org/10.9790/2402-081245063

- Mamdouh AG,El Sayed GK,Ahmed AA (2003).A comparative study of nicotine effect on the liver of albino rat. Egypt. J. Hospit. Med., 10: 130-144. https://doi.org/10.21608/ ejhm.2003.18738

- Marinucci M, Bodo S, Balloni P, Locci T, Baroni (2014). Subtoxic nicotine concentrations affect extracellular matrix and growth factor signaling gene expressions in human osteoblasts. J. Cell Physiol., 229(12): 2038-2048. https:// doi.org/10.1002/jcp.24661

- Maritz GS, Burger B (1992). The influence of maternal nicotine exposure on neonatal lung carbohydrate metabolism. Cell Biol. Int. Rep., 16: 1229-1236. https://doi.org/10.1016/ S0309-1651(06)80039-1

- Marklund S, Marklund G (1974). Involvement of superoxide anion radical in the autooxidation of pyrogallol and convenient assay for superoxide dismutase. Eur. J. Biochem.,
47: 469-474. https://doi.org/10.1111/j.1432-1033.1974. tb03714.x

- Meister A (1994). Glutathione, ascorbate and cellular protection. Cancer Res., 54: 1969-1975.

- Nash JE, Persaud TVN (1988). Influence of nicotine and caffeine on rat embryonic development. Histol. Histopath., 3: $377-388$

- Ozukutat BH, Ozkan KU, Ibrahim CF, Guldur E, Kilin MS, Inan F (2005). Effects of maternal nicotine exposure during on breast-fed rat pups. Biol. Neonats, 88(2): 113-117. https://doi.org/10.1159/000086130

- Parks DA, Bulkley GB, Granger DN (1983). Role of oxygen free radicals in shock, ischemia, and organ preservation. Surgery, 94(3): 428-432.

- Rochling FA (2001). Evaluation of abnormal liver tests. Clin. Cornerstone, 3(6): 1-12. https://doi.org/10.1016/S10983597(01)90074-2

- RosenbergJ, Bonwitz NL, Jacob,Wilson KH (1980). Disposition kinetics and effects of intravenous nicotine. Clin. Pharmacol. Ther., 28: 516-522. https://doi.org/10.1038/clpt.1980.196

- Rowell PP, Clark MJ (1982). The effect of chronic oral nicotine administration on fetal weight and placental amino acid accumulation in mice. Toxicol. Appl. Pharmacol., 66:30-38. https://doi.org/10.1016/0041-008X(82)90058-8

-Schumann G, Klauke R (2003). New IFCC reference procedures for the determination of catalytic activity concentrations of five enzymes in serum: preliminary upper reference limits obtained in hospitalized subjects. Clin. Chim. Acta, 327(12): 69-79. https://doi.org/10.1016/S0009-8981(02)003418

-Shacka JJ, Fennell OB, Robinson SE (1997). Prenatal nicotine sex-dependently alters agonist-induced locomotion and stereotypy. Neurotoxicol. Teratol., 19: 467-476. https://doi. org/10.1016/S0892-0362(97)00063-9

- Sheng PH, Yuen TS, So LH, Cho HC (2001). Hepatotoxicity of prenatal and postnatal exposure to nicotine in rat pups. Exp. Biol. Med., 226: 934- 939. https://doi. org/10.1177/153537020122601009

- Simeonova R, Kondeva-Burdina M, Vitcheva V, Mitka Mitchev $M$ (2014). Some in vitrol in vivo chemically-induced experimental models of liver oxidative stress in rats. Hindawi Publ. Corp. BioMed. Res. Int., Volume 2014, Article ID 706302, 6 pages. https://doi.org/10.1155/2014/706302

- Smith SM, Grisham MB, Manci EA, Granger DN, Kvietys PR (1987). Gastric mucosal injury in the rat: Role of iron and xanthine oxidase. Gastroenterology, 92: 950-956. https:// doi.org/10.1016/0016-5085(87)90969-3

- Speakman JR (2003). Oxidative phosphorylation, mitochondrial proton cycling, free-radical production and aging. Adv. Cell Aging Gerontol., 14: 35-68. https://doi.org/10.1016/ S1566-3124(03)14003-5

-Suriyaprom K,Harnroongroj T, Namjuntra P,Chantaranipapong Y, Tungtrongchitr R (2007). Effects of tobacco smoking on alpha-2-macroglobulin and some biochemical parameters in Thai males. Southeast Asian J. Trop. Med. Publ. Health, 38(5): 918-926.

-Tajima K, Takeuchi K, Suzuki S (1988). Risk factors for liver dysfunction in middle aged men based on four years health examination data. J. Occupant. Health, 40(4): 339-344. https://doi.org/10.1539/joh.40.339

- Tessa C (2019). Tobacco use during pregnancy. Clin. Obstet. Gynecol., 62(1): 128-141. https://doi.org/10.1097/ GRF.0000000000000413 
-Tetley TD (2006). Proteinase inhibitors/secretory leukoprotease inhibitor and elafin. In: Laurent GJ, Shapiro SD, editors. Encyclopedia of respira-tory medicine. London: Academic Press. https://doi.org/10.1016/B0-12-370879-6/00330-6

- von Ziegler NI, Schlumpf M, Lichtensteiger W (1991). Prenatal nicotine exposure selectively affects perinatal forebrain aromatase activity and fetal adrenal function in male rats. Dev.Brain Res., 62(1):23-31.https://doi.org/10.1016/01653806(91)90186-M

-Walter JB, Israel M (1996). General pathology. Churchill Livingstone, New York, $7^{\text {th }}$ Edition.

- Wetscher GJ, Bagchi M, Bagchi D, Perdikis G, Hinder PR, Glaser K, Hinder RA (1995). Free radicals production in nicotine-treated pancreatic tissue. Free Radic. Biol. Med., 18: 877-882. https://doi.org/10.1016/0891-5849(94)00221-5

-Whitehead TP, Robinson D, Allaway SL (1996). The effects of cigarette smoking and alcohol consumption on serum liver enzyme activities: A dose-related study in men. Annals of clinical biochemistry: Int. J. Biochem. Lab. Med., 33(6): 530-535. https://doi.org/10.1177/000456329603300607

- Yagi K (1987). Lipid peroxides and human diseases. Chem. Phys. Lipids, 45: 337-351. https://doi.org/10.1016/00093084(87)90071-5

- Yildiz D, Ercal N, Armstrong DW (1998). Nicotine enantomers and oxidative stress. Toxicology, 130: 155-165. https://doi. org/10.1016/S0300-483X(98)00105-X

-Yuen ST, Gogo AR, Luk IS, Cho CH, Ho JC, Loh TT (1995). The effect of nicotine and its interaction with carbon tetrachloride in the rat liver. Pharmacol. Toxicol., 77: 225230. https://doi.org/10.1111/j.1600-0773.1995.tb01017.x

- Zaren B, Cnattingius S, Lindmark G (1997). Fetal growth impairment from smoking: Is it influenced by maternal anthropometry? Acta Obstet. Gynecol. Scand., 165: 30-34.

-Zhang, Ratchffe JM (1993). Paternal smoking and birth weight. 83(2): 267-269. https://doi.org/10.2105/AJPH.83.2.207 